\section{Biotech company fights to keep tips on data access private}

\section{Jim Giles, London}

An agricultural biotechnology company is asking a British court to prevent an environmental group releasing guidelines that would help the public probe pesticide trials.

Friends of the Earth, the Londonbased environmental group, wants to publish its knowledge on how to gain access to data. But Bayer CropScience of Monheim, Germany, says this would reveal commercially sensitive material to competitors, and is seeking a court injunction to prevent publication.

The guidelines draw on the environmental group's four years of legal struggles with Bayer over glufosinate ammonium, a pesticide used with a transgenic maize developed by the company. The pesticide was cleared for experimental use a decade ago, after the UK government's Pesticides Safety Directorate examined Bayer's data on human toxicity and environmental impact.

When Friends of the Earth first asked the directorate for those data in 2000 , Bayer objected on the grounds of commercial sensitivity. The environmental group gained access last May - but could view the information only at the offices of Bayer's lawyers and could not copy or remove the documents.

Now the group wants to publish guidelines on how to access such data in Britain, including an array of procedural options beyond those used in the glufosinate ammonium case.

Last October, Bayer applied for an injunction to stop this, claiming that the information would encourage lawbreaking by providing access to information it wants to be confidential. "It is very easy to access information people just have to approach us," says Bayer spokesman Julian Little. "But under the Friends of the Earth guidelines we will lose control of the data."

Friends of the Earth lawyer Phil Michaels says that the law will continue to protect commercially sensitive content, such as details of the active ingredient in the pesticide. "This is an absurd situation," he says. "The information is already available to the public. We just want to tell people how to access it."

Neither side will discuss what the guidelines actually say, until the court hears the case, which Michaels says could happen by June.

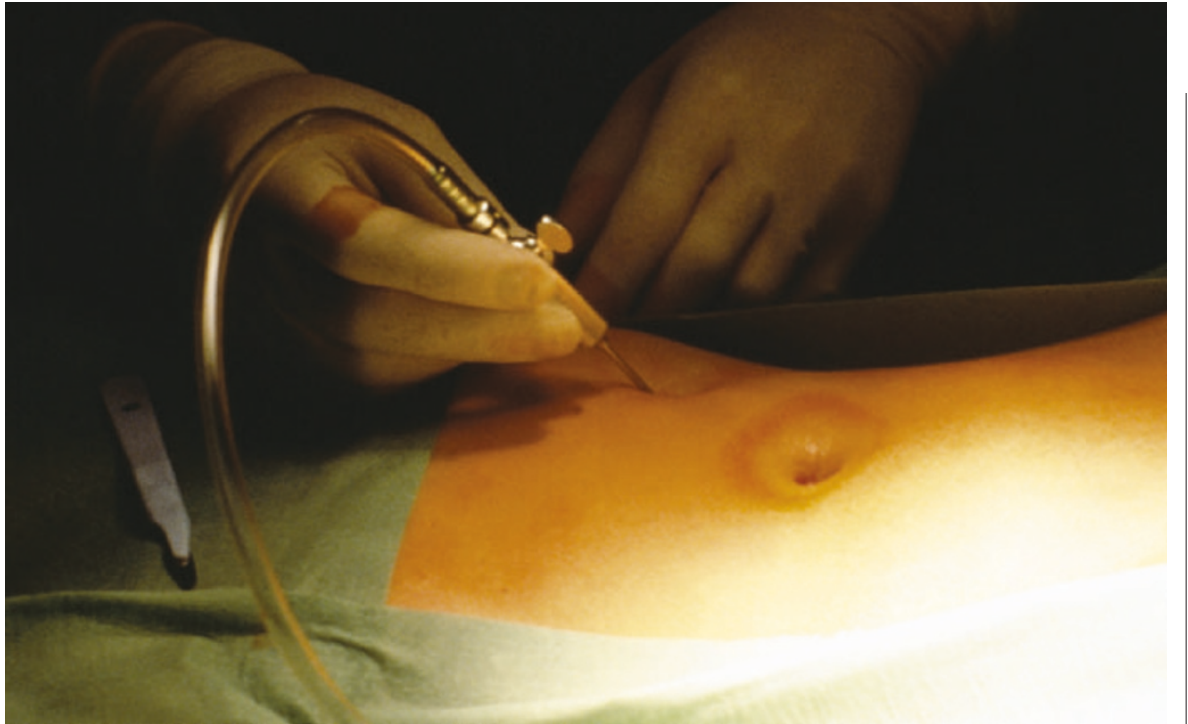

Baby boom: techniques such as egg harvesting, and concern about their effects, are both on the up.

\title{
Ethics council calls for probe into assisted reproduction
}

Erika Check, Washington

The health impacts of techniques used for assisted reproduction should be investigated in a comprehensive study supported by the federal government, according to a report by advisers to President George Bush.

The study would examine whether assisted reproduction is associated with higher rates of health ailments in children, such as genetic abnormalities and birth defects, as has been suggested by some smaller assessments (see Nature 422, 656-658; 2003).

The call comes amid growing concern in the United States about the rapidly expanding and largely unregulated assisted-reproduction industry. During the past 25 years, a million couples have borne children through such techniques. Pressure is building for Congress to regulate some aspects of the industry, such as the fact that new techniques do not require regulatory approval before being used in patients.

On 30 March, the President's Council on Bioethics, chaired by University of Chicago ethicist Leon Kass, issued a report on the topic - Reproduction and Responsibility: The Regulation of New Biotechnologies.

The report recommends that a more extensive investigation into the health effects of assisted reproduction should be incorporated into the National Children's Study (NCS), a major study of child health that has been in preparation since 2000 .

Peter Scheidt, a paediatrician at the National Institute of Child Health and Human Development who directs the NCS, says that the study will almost certainly address assisted reproduction if it receives funding. But last month, an advisory committee to the child health agency warned that the NCS's sample population of 100,000 children would probably not be enough to tell whether assisted reproduction contributes to rare abnormalities.

The council's report also said that the government should study the health of egg donors and those who give birth to children through assisted reproduction. And it recommends that professional societies and the government should more tightly regulate the medical practice of assisted reproduction.

The bioethics council's work is always controversial, and this most recent report is no exception. At the council's meeting on 1 April, one of its members, endocrinologist Daniel Foster, questioned whether the removal of cell biologist Elizabeth Blackburn last month - and her replacement by nonscientists - would skew the council (see Nature 428, 4; 2004). "There is a concern that there is now going to be an imbalance," Foster says.

And although the report took no position on whether human embryos should be cloned to produce stem cells, some council members expressed concern that lawmakers might use the report to argue for a ban. In a personal statement appended to the report, council member Janet Rowley, a cell biologist at the University of Chicago, warned that she believed Congress might use some of the options outlined in the report "to do real damage to beneficial research and medical treatment".

Scientists' advocacy groups reacted cautiously to the report. "There is much in this report we can support," said Marian Damewood, president of the American Society for Reproductive Medicine, in a statement. "The call for follow-up on outcomes of children conceived with the use of reproductive technologies is very timely." 